\title{
Emirati students encounter Western teachers: tensions and identity resistance ${ }^{1}$
}

\author{
Ibrahima Diallo \\ University of South Australia
}

\begin{abstract}
This paper discusses tensions and identity resistance in a cross-cultural educational context in the United Arab Emirates. It focuses on how Emirati students, living and socialised in a conservative ArabicIslamic society and shaped by Islamic values and epistemologies, construct their cultural identities while learning English with their Western-trained teachers, who are influenced by liberal ideologies and secular epistemologies. To understand the complex engagement between Emirati students and their Western-trained teachers this article uses both phenomenography and reflection on critical incidents to explore, investigate and interpret Emirati students' intercultural experience with their Western-trained teachers and to highlight the tensions and identity resistance that arise from this educational encounter.
\end{abstract}

\section{Introduction}

As English becomes a lingua franca through globalisation, the hiring of Western-trained teachers to teach English is becoming prevalent in many countries where English is not the main language. This is especially true in the United Arab Emirates (UAE) where a large number of Western-trained teachers are recruited to teach English. However, large-scale importation of Western-trained language teachers to teach in a non-Western educational context poses challenges because teachers and students tend to operate from within their own distinct social, cultural and educational paradigm. Teachers draw on Western educational models and pedagogies to teach students who have different, if not opposing, educational values and epistemologies. While Western-educated teachers are the natural product of liberal and secular upbringing and education, Emirati students are not only the product of their Islamic education and upbringing but also live and socialize in a conservative Islamic context. Equally relevant to this educational setting is that learning a foreign language is a complex process that involves constructing or negotiating new identities to accommodate new values in order to function effectively in the target culture. This entails Emirati students' ability to adopt new values but at the same time filter and, wherever necessary, resist aspects of the target culture. In this article, 'Western-trained teacher' is used as an umbrella term that encompasses teachers with substantial training and exposure to Western education and epistemologies regardless of their nationality. Western-trained teachers referred to in this article may be native or non-native speakers of English.

This article focuses on the ways in which Emirati students respond to their Western-trained teachers and how they construct their identities in this cross-cultural educational context. It is based on my five years' professional experience in the UAE as a language teacher (of French and English) and as a lecturer in applied linguistics. It draws also on interviews conducted with Emirati students in two secondary schools (one in Dubai and one in Abu Dhabi), in one tertiary institution (in Abu Dhabi) and in a private institution teaching French language and culture (in Abu Dhabi).

Phenomenography, developed originally to investigate students' approaches to learning experiences (Marton, 1981) is adopted as a framework to explore, investigate and interpret Emirati students' 
learning experiences with their Western-trained teachers. This article discusses critical incidents in the classroom setting to highlight the tensions and identity resistance that arise from this educational encounter. The article begins with the context of the study by discussing the complex UAE education system characterized, on the one hand, by the encounter between two different cultures and, on the other hand, by a complex sociolinguistic setting where two different languages each fulfil a particular function. Next, the article presents an overview of the Islamic and Western education traditions and epistemologies that interact in UAE classrooms. The fourth section discusses identity from different perspectives, while the fifth focuses on phenomenography as a reflection/research approach. The final section discusses a range of critical incidents that occurred in the UAE education setting, in order to highlight the tensions that arise from this cross-cultural encounter, and how Emirati students construct their identities.

\section{Context of study}

\section{Linguistic-cultural dualism in the UAE}

Despite its relatively young age as a nation and its small population, the UAE is one of the richest countries in the world thanks to revenues generated from its oil and gas resources (Wilkins, 2001). To sustain and expand its remarkable economic and financial growth, the UAE relies extensively on expatriates from around the world to run its country, with more than $80 \%$ of the population being expatriates (Reinert \& Rajaan, 2009). These expatriates work in various sectors, including health, banking, retail, construction, and energy resources; however, because of the country's pressing need to train its own people so they can successfully integrate in the job market and take responsibility for their own country, education is one of the sectors with the largest representation of expatriates, and one where they are most visible.

Arabic is the only official language of the UAE. As such it is widely used in government, public services, education, and the media. It is also the language of socialisation, and therefore the most important link between Arab expatriates from different Arab countries and the Arab diaspora. Most importantly, besides playing a crucial social and professional role, Arabic is above all the language associated with Islamic beliefs (the language of the Qur'an) and Arab identity. As such, it carries a powerful spiritual and religious symbolic value to the UAE's national identity as an Arab and Muslim country: Arabic, argues Ahmed, "unlike many other languages, is not just a language of communication, it is the basis of the religion which is pivotal to the whole way of life, the culture and the cultural identities of its members" (2011, p. 125).

In parallel with Arabic, English also has a significant role in the UAE, despite not having official status. English is widely used in business and in the private and public services (including banking, health and education). In public and private tertiary education institutions the use of English has not only increased, but has taken over from Arabic in most of the tertiary education level: the majority of courses in local and foreign universities (especially sciences and economics courses) are delivered in English. Similarly, the use of English has strengthened recently at the public pre-tertiary education level, bolstered by the government's push (in the mid-2000's) to raise the standard of students' English and to teach sciences and technology subjects in English in selected state secondary schools.

From a sociolinguistic perspective, English also plays a major role as it is the most used lingua franca between the Arabic and the non-Arabic speaking communities as well as by non-Arab expatriate communities from different parts of the globe who live, work and socialize in the UAE, namely Europeans, North Americans, Asians, and Africans. However, this rapid growth of English has raised 
concerns about the long-term future of the Arabic language and culture in the Gulf Countries in general, and in the UAE in particular. Many believe that Arabic is being seriously threatened both by the increasing use of English in schools and by the expeditious and pervasive Westernisation of the education system, influenced by Anglo-American education models. For example, Ahmed (2011) believes that "many feel that marginalization and cultural loss is inevitable in such circumstances. Those who are affiliated with Arabic language and culture feel they are being erased" (p. 125), while others, such as Maalouf (2000, cited in Ahmed, 2011, p. 126), argue that in countries such as the UAE, "the national language would soon be used for domestic purposes only and would end up as a mere local dialect". As a result, according to Findlow (2006):

there is a pervasive feeling that [school] subjects dealing explicitly with values, ideas, 'culture' should be taught according to traditional Arab-Islamic models, and in Arabic, despite the availability of international frameworks - particularly among the Islamisation lobby. (p.27).

Given the huge benefits that knowledge of English offers both in the country and in the world marketplace, especially for education, employment, socialisation and mobility, the UAE hires a large number of Western-trained teachers. These teachers are recruited to teach in schools and universities and they also play a significant role planning and overseeing the large-scale policy education changes and implementation undertaken by the federal government as well as by local governments, whose stated aims are to modernize the entire education system and align it with international standards.

Interestingly, this encounter between Emirati students on the one hand, and Western-trained teachers on the other, is taking place, as discussed above, while "educational institutions in the UAE are undergoing tremendous changes" (Ibrahim et al, 2013, p. 2) and while there are strong pressures from within to ensure these changes and education reforms are consistent with the country's Arabic traditions and Islamic values. This context has made the UAE education system one of the most interesting sites in the world for cross-cultural interaction between Western-educated teachers and students of Arab-Islamic background. Therefore, the UAE education context as a whole provides fertile ground for understanding the ways in which Emirati students learn English and, at the same time, negotiate and construct their own identities. The imported Western-trained language teachers in the UAE, like any other teachers elsewhere, are far from 'neutral'. They are highly positioned even before they enter local classrooms, given that they embody Western Judeo-Christian epistemologies, liberal views and secular traditions. Furthermore, Syed (2003), discussing ELT teaching in the broader context of the Gulf Countries, argued that

Although foreign teachers bring diversity into the classroom, and although some use contextually situated pedagogy, there are wide gaps in the expatriate educators' (especially non-Arabs) knowledge of local sociocultural communities and languages. Linguistic and cultural distance between learners and teachers is a serious factor in the Gulf EFL classroom. (p. 338-339)

This section has discussed the complex sociolinguistic and sociocultural context of the UAE by highlighting what is referred to as the linguistic dualism (see Boyle, 2012; Clarke 2007; Findlow, 2006; Karmani, 2005) in the UAE with the respective role of Arabic and English in the social-professional and education context of the country. It has also discussed the encounter between Western-trained teachers and Emirati students in this complex setting. It shows that the complexity of the UAE education context with reference not only to the encounter between two opposing education traditions, but also to the sociolinguistic context and the language-education policies undertaken in the country. The next section discusses key points of both Islamic education and Western education frameworks. 


\section{Islamic education framework}

The education system of the UAE is strongly influenced by Arab and Islamic values, education models and epistemologies. It is constructed on Islamic religious philosophies, and one of its aims is to promote an Islamic way of life. Knowledge and education are designed so that they are consistent with Islamic religious conventions and teachings. For example, in her discussion of education in the UAE, Findlow (2008) argues that

throughout the remainder of the $20^{\text {th }}$ century, the country's successive education policies trailed a fairly consistent path of religious observance. (p.344)

illustrating this with reference to a UAE policy document from 1996 which

directs educational policy towards [...] abiding fully by Islamic teachings and giving prominence to the comprehensive nature of Islam. (cited ibid)

Generally speaking, the Islamic education model can be said to be influenced by three interrelated key Islamic concepts. One is the Islamic concept of 'aqeeda or religious creed, which stipulates that Islamic religious teaching and injunctions (as opposed to our understanding or application of them) remain unalterable and are not negotiable. At the same time, it emphasizes that faith must always supersede rational or scientific argument; faith remains central and all-encompassing and must therefore be used as a framework for reasoning and interpreting facts and events. Even though critical thinking and rational knowledge processing are encouraged in Islamic education and epistemology, they are permitted as long as they do not contradict Islamic teachings and must follow the principle of tafakkur, that is:

thinking in the perspective of the revelation of the Qur'an and the teachings of the Hadiths and accepting every single Islamic truth. (Blaik-Hourani et al., 2011, p. 345)

Islamic education is also strongly influenced by the concept of al-haqiqa al-mutlaqa which emphasizes the existence of one God only and one absolute truth. This concept can be related to 'aqeedah in the sense that faith is paramount in analyzing and understanding the world. Truth, like God, is singular; therefore, the Islamic framework must supersede others and must lead to one truth that cannot be challenged.

The third concept with an impact on Islamic education is Allahu a'lam. It intersects with the concepts discussed above, and means that only God knows. In other words, absolute knowledge is not attainable by a simple human being; it is the privilege of God alone to know the ultimate truth. By indicating that knowledge is a divine prerogative, Islamic education frames the methods and 'lends the eyes' through which knowledge, which emanates from God, is to be accessed.

These three important key features have influenced and shaped Islamic education and epistemologies, which have spread through the traditional Qur'anic education system via mosques (masjid and kuttab) and madrasahs. Not only have these features shaped Islamic epistemology, but they have also considerably influenced Islamic teaching practices and philosophy. Basic education and the transmission of Islamic knowledge rely on repetition, drills and memorization as their key learning methods. Memorization and recitation are important for the Muslim because to perform religious duties and rituals one needs to be able to recite Qur'anic verses or extracts that are memorized. Qur'anic knowledge is also central beyond religious practices alone. Qur'anic knowledge is equally important for observance of Islamic codes of behaviour as well as establishing connections with God and all living creatures. As highlighted by Barazangi: 
Islamic education is the process of shaping character within the Islamic worldview, as well as exposing the individual to all knowledge as a means of understanding and forming a constructive relationship with God, other humans and nature. (1995, p. 2)

The foundations of Islamic education are best summarized in a quote from an interview with Seyyed Hossein Nasr, professor of Islamic studies at George Washington University:

First, you have the Qur'annic revelation. Then there is the conveying of the Islamic revelation by the Prophet, 'alayhi as-salätu wa'l-salām, and his Sunna and Hadith and the establishment of the earliest Islamic community... (Nasr, 2012, p. 7)

Islamic epistemologies and education practices described in this section continue, to a large extent, to hold considerable sway over the current education system in the $U A E$, in terms of its general philosophies and epistemology. Findlow $(2008$, p. 348$)$ reached a similar conclusion in her study on the role of higher education in the UAE nation-state development and identity construction between 1971 and 2000. Her survey of UAE students conducted between 1997 and 2000 at three universities found " that Islam was considered to be a more important element of the curriculum" (p.348).

In the UAE, despite recent large-scale efforts to liberalize and Westernize its education system (such as establishing and authorising foreign institutions to operate and deliver international programmes), observance of Islamic values and codes of practice remain extremely important in both state-run and private institutions - although less prominent in private institution curricula. For example, in 1991, the Ministry of Higher Education and Scientific Research outlined its objectives and responsibilities, which included:

to place emphasis on the principles and precepts of the true religion of Islam and to provide learners with Islamic and Arab culture. (Cited in Findlow, 2008, p. 344)

Along the same lines, the Ministry of Education Strategy 2010-2020 stipulates that it aims to "develop Islamic education curriculum to form forgiving Muslim students" (Ministry of Education 2008, p. 2). On the specific area of desired outcomes, this document highlights educating students who cherish

their national identity, embracing the UAE's history, culture, and Islamic values, and promoting forgiveness and tolerance. $(2008$, p. 5)

These views on education and epistemology in the UAE are encapsulated in the country's constitution:

Islam is the official religion of the Union. The Islamic Shari'a shall be a main source of legislation in the Union. The official language of the Union is Arabic. (UAE Constitution, Article 7).

\section{Western education framework}

The Western education model, in comparison with the Islamic education model, is influenced by secular and liberal epistemologies. It is relatively distant from religious influence and has developed its own rationale and methods of inquiry. With the influence of positivist thinkers, it assumes that knowledge is attainable and demonstrable. Knowledge, which was in previous Western tradition seen as in the domain of religion (or God), only, is 'freed' from religious grip and 'liberalized': anyone can access knowledge by following coherent, sensible and rational approaches. It is important to point out that despite being secular, the Western education model remains influenced by Judaeo-Christian values although by tradition rather than by method - because of the significant role played by the church and sometimes by Jewish religious institutions and individuals in the establishment and the spread of western knowledge and its education traditions in and outside Europe. The impact of secular ideologies has been significant in knowledge construction and scientific inquiry. Reasoning and rational approaches outside of religious frameworks are at the forefront of the Western education model, and the recognition of rational thinking and critical attitude has influenced Western educational pedagogies, 
leading to a host of new perspectives. Learning theories are revisited and cognitive learning received a considerable boost thanks to constructivist learning theories instigated by Piaget $(1937,1967)$ and Vygotsky (1978). As a result, the understanding of learning shifted from mere repetition of patterns or mimicry of models to (in principle) a deliberate, individual, conscious and active process that leads to knowledge building and fact-finding. In the learning process, multiple interpretations and views are encouraged and accepted because they are part of rational and critical thinking process.

In the Western education framework, students are often expected to monitor their own learning. They are not merely recipients of ready-made ideas and solutions; rather they are individuals who participate actively in knowledge-gathering and interpretation. Students can use their (previous) knowledge and experiences to assess their own points of view and can compare and contrast their understandings with different ones. Importantly, students can question and interpret facts and challenge them in the light of new experiences, knowledge and evidence (Zevin, 2000).

To summarize the discussion above, it can be said that Islamic and Western education models differ in terms of ideologies and attitudes toward knowledge. While the Islamic education model focuses on education and knowledge that are constructed within the Islamic religious framework, Western education emphasizes education and knowledge from outside religious boundaries. Even though both encourage rational thinking and critical approaches to knowledge, Islamic education recommends that:

knowledge must be approached reverently and in humility, for there cannot be any 'true' knowledge that is in conflict with religion and divine revelation, only ignorance [... because] the appropriate use of knowledge from a Muslim perspective is to help people to acknowledge God, to live in accordance with Islamic law and to fulfil the purposes of God's creation. (Halstead, 2004, p. 520)

In contrast, Western education is constructed on liberal epistemologies and secular knowledge, and reasoning outside religious constraints is seen as "the engine of change and progress" (Kazmi, 2003, p. 262).

\section{Analytic approach}

\section{Identity construction}

Identity is a complex notion because it not only includes ethnicity, race, gender religion and other elements, but also is constructed on individual, group, community and national levels. In current research, identity is examined from two broad perspectives. On the one hand, identity may be treated as relatively fixed, uniform and unchanging: a view known as essentialism. For essentialists, identity has one core that is "originary, integral and unified" (Hall, 1996, p. 1). Others reject essentialist views, arguing that

identity does not signal that stable core of the self, unfolding from beginning to end through all the vicissitudes of history without change. (Hall and Du Gay, 1996, p. 3)

They believe that identity is a dynamic process that evolves and is subject to changes (Hall, 1996, 1997; Woodward, 1997). Given the changing nature of identity, such scholars as Holland (1996) and Hall (1997) posit that identity is multiple; that is: "in different contexts and at different times, different identities" (Holland, 1996, quoted in Phan, 2007, p. 21).

In the case of Emirati students, interaction in the classroom with 'Others' (Western-trained teachers) embodying different educational traditions, culture and lifestyles, impacts on the ways in which students perceive themselves, and the ways they negotiate and construct their own identities. As highlighted by Woodward, identity 
marks the ways in which we [are] the same as others who share that position and the ways in which we are different from those who do not. (1997, pp. 1-2)

It can be said that Emirati students use these Others as a reference point to define their own identity as individuals and as a group sharing the same cultural references (the Self). Students' understanding of both the Western-trained teachers and of their own identities is formed against the backdrop of two different, if not opposing, educational, cultural and religious models.

Emirati students' engagement, or lack of it, with their Western-trained teachers, necessarily affects the way they perceive themselves and the way they relate to Others (and to Westernness in particular). This view can be illustrated by ideas developed by, among others, Hall (1996) and Woodward (1997). According to Hall, the construction of identity is an effect of the presence of, or is in reference with, Others. He argues that identity "has to go through the eye of the needle of the Other before it can construct itself" (Hall 1991, p. 21 cited in Grossberg, 1996, p. 89): we see ourselves and construct our identity through the eyes of the Other. In a similar vein, Woodward (1997) contrasts identity with the Other as well as with the context that shapes, defines and influences it. He emphasizes that identity "gives us an idea of who we are and of how we relate to others and to the world in which we live" (p. 1).

On the part of the Emirati students, identity tensions and resistance may be determined by, and may arise through, a host of factors including, but not limited to, Westernness (i.e. an essentialized view of the West and Western people), Occidentalism ((mis)representation and (mis)construction of Western cultures and ways of life), real or imagined neo-imperialism, or post-colonialism (Western vs. Oriental; colonizer vs colonized). Therefore, the prism through which Emirati students perceive their Westerntrained teachers is not necessarily founded only on religious, epistemological and cultural differences: the ways they construct the Other may be also accounted for by images or relics from the past as well as those from the present because identity can also be "tied to a specific history and culture, which created a 'positioned' context determining the 'self' of a person" (Hall, 1997, p. 89).

To add to the complex mix of identity, scholars have looked at identity from a wide range of other perspectives. Reed (2009), for example, analyses identity negotiation using a triple metaphor: fastening, unfastening and refastening identities. He argues that 'identity fastening' is "the work that individuals do to claim insider status for themselves and for others" (Reed 2001, p. 329). By this he means that even though identities are sometimes fastened by laws, conventions or categories (e.g.: group identity, sense of belonging, etc.), they are negotiated and intentional. Identity unfastening, on the other hand, occurs in multiple ways and relates to individual standpoint. He argues that identity unfastening

often happens when individuals move from one cultural context into another where the norms and rules for membership are different (ibid.),

and may be voluntary or involuntary. As for identity refastening, Reed describes it as an "on-going identity formation process" (p. 337) because people may take on new identity markers to fit into a new social and cultural context. For example, he mentioned naming practices among migrant communities who refasten their identity by adopting names that make them 'less foreign' and blend in their new geographic space (p. 336). The identity fastening metaphor seems to be relevant to the Emirati students in this context: with the presence of their Western-trained teachers, they intentionally fasten their identity by creating group solidarity among themselves, but at the same time they are in a perpetual process of identity formation tied to the presence of the Other.

This section has discussed the complexity of defining identity, given the cultural and psychological factors involved and the fact that identity is something not fixed but dynamic and changeable. The next section discusses the research approach of this study: phenomenography and critical incidents. 


\section{Phenomenography}

Phenomenography is used here as a framework to understand and discuss the tension and identity resistance in the educational context of the UAE between Emirati students and their Western-trained teachers. Phenomenography is an empirical research method that seeks to "describe the world as people experience and explain it" (Barnard et al., 1999, p. 213). According to Marton, who introduced this ground-breaking approach in education research, phenomenography

aims at description, analysis, and understanding of experiences; that is, research which is directed towards experiential description" (Marton, 1981, p. 180).

This study adopts a phenomenographic approach because it is a powerful research tool that allows us to describe, analyze and understand the ways in which students experience their interaction and construct their identity with their teachers, who operate in an educational and pedagogic context different from their own. The use of critical incidents is based on the phenomenographic premise, which is to understand "anything that can be said about how people perceive, experience and conceptualise" (Marton, 1986, p. 180).

To describe how Emirati students experience and explain their identity in the presence of the Other, I discuss phenomenography in light of critical incidents that occurred in the classroom. By so doing, I hope that the critical incidents expand our understanding of the tensions and identity resistance in the cross-cultural classroom setting. Critical incidents, that is, "any vividly remembered event" (Brookfield, 1990, p. 84) seen as significant by any participant, have been an important component of reflective teaching. By no means necessarily typical, the critical incidents discussed here have critical significance in this context in the sense that they highlight the tension between the experience of Emirati students and that of their Western-trained teachers.

This section has discussed identity from essentialist and non-essentialist perspectives, and analyzed phenomenography and critical incidents as frameworks to understand how Emirati students respond to their Western-trained teachers and to elicit the tensions and identity construction in a cross-cultural educational encounter.

The following section addresses the tension and identity resistance of Emirati students by discussing critical incidents that occurred in classroom settings in the UAE.

\section{Tension and identity resistance}

In this section, tension and identity resistance cases that occurred in classroom settings in the UAE and involving Emirati students are discussed in the light of critical incidents and a phenomenographic approach.

In the context of the UAE, textbooks and other classroom teaching materials are the most common areas where students show resistance. This is understandable because these are the means through which students are exposed firsthand to the cultures and practices of the target (language or disciplinary) community. Therefore, it is expected that materials represent or incorporate significant aspects of the target culture. The crucial question that arises here is about the representativeness, the authenticity and, above all, the social and cultural relevance of the content covered by textbooks used to teach Emirati students. It is important to understand to what extent the language (variety) and the culture portrayed in a textbook represent the actual language, culture and society it purports to teach about; the language in textbooks 
is generally fragmented and highly generalized, indicating only the norms of behaviour [...] Textbook users may assume that information about, for example, the way some individuals behave, applies to the culture as a whole, which easily gives rise to prejudice and stereotype (Yuen, 2001, p. 460)

There are other concerns about textbooks. Canagarajah (1999), for example, argues that textbooks "project ideologies taken for granted by Center communities as natural and legitimate" (p. 87). To support this view he gives the example of textbooks used to teach Sri Lankan students which he found "contain certain biases regarding appropriate language use" (p. 86), but also that the narratives in these textbooks "contain partisan values" (p. 87).

In addition to being the means through which aspects of the target culture are represented, Yuen (2001) argues that textbooks also represent non-Center cultures in a particular, systematic way. In other words, textbooks are not innocent or neutral, but are fundamentally ideological in the sense that they are produced by particular vested linguistic, socio-political and cultural agendas. More broadly, Phillipson (1992, 2009) argues that English is not an innocent, value-free, neutral language for global communication.

In the UAE, as in many other contexts, textbooks have a central place not only for teaching institutions ${ }^{2}$, but also for both students and their families. These stakeholders keep a close watch on textbooks because they are the yardsticks against which teacher performance is assessed and students' learning progression measured. Therefore, the contents of textbooks are generally under scrutiny by institutions, students and parents.

As highlighted by Canagarajah (1999),

depending on their own cultural and discursive backgrounds, students can adopt various strategies to receive, resist, or reconstruct the messages of the text. (p. 89)

As with the Sri Lankan students mentioned by Canagarajah, I witnessed frequent glosses, scribbles and graffiti in textbooks. These indicated ways used by Emirati students to resist, reconstruct and, at the same time deride cultural representations that are alien to them or inappropriate in their culture. The most common glosses in students' textbooks are found on pictures. Generally, pictures showing (Western) female characters dressed in a way they would not have expected are shaded (in dark color) or struck out. When quizzed about this, the reply is generally, "Teacher, this is haraam"; with a finger pointing to the sky. Similarly, as an act of resistance (and derision), male characters pictured in textbooks are often modified by students to fit their own image, for example by adding a beard or UAE male headscarf.

Besides these cases of resistance to textbooks' illustrations, the Emirati students expressed resistance to textbooks in other ways. For example, our experience in the UAE educational context, supported by a range of interviews with Western-trained teachers, shows that students are resistant when their teachers focus on Western cultural, literacy and artistic themes (topics) that highlight only prominent Western thinkers and artists. Personal interviews and research in various institutions showed that students resisted studying well-known Western writers and their works, such as Shakespeare (e.g., Hamlet), Flaubert (e.g., Madame Bovary), and Molière (e.g., Le Malade Imaginaire). For these students, their own literature and poetry, which deal with more serious issues, such as praising God (Allah) would have been more relevant. As a result, they questioned why their own values were not highlighted, and instead pushed to the background. Even though the aims of teaching these European classics were to broaden their intercultural knowledge, the students resisted on the grounds of cultural relevance and identity. Indeed, the most revealing form of resistance for me came from a student (with strong religious views) who not only indicated his aversion to the textbooks used to teach English, but also 
questioned, on linguistic, religious and cultural grounds, the reasons why students were "imposed" (to learn) English in the first place.

Teaching literature can be a source of both tension and resistance. For example, in Western literature depictions of gods, God, saints and other religious figures are accepted, and the author may be considered to possess admirable artistic talent and creativity. However, in Muslim literary traditions and epistemologies, similar representations are highly sensitive and contentious, as in the example discussed by Blaik-Hourani et al. (2011) of teaching the play Everyman - a morality play set in the medieval era in which God and the Angel of Death appear as main characters.

In Western contexts, giving human qualities to God or representing God and/or religious figures in literary and artistic works is also acceptable, but in Islamic contexts, it is strictly forbidden and, therefore, offensive. Therefore, it is no surprise that UAE students do not accept the idea of visual representations of God or a prophet because it goes against their own identities and values. This may be because, when faced with a Western-trained teacher using Western literary canons, they feel that their identity is in question or under threat. In discussing the experience of teaching Western literary classics in the UAE, Blaik-Hourani et al. (2011) indicated that one of the authors successfully taught Chekhov's The Lady with the Dog - a short story in which both main characters are involved in extramarital affairs without tension or resistance because it was presented to the students as a manifestation of the Western 'alien' or an enactment of the Other (see further discussion of this example below).

As can be seen here, textbooks and teaching materials (including aspects of the literature of the target language) may prompt tension or resistance in the classroom and at the same time they demonstrate how Emirati students negotiate their identity in their cross-cultural education encounters with Western (trained) teachers.

Certain topic areas, including among others Western culture and lifestyles, gender issues, and politically sensitive topics, may also be associated with tension and resistance in the classroom. As discussed earlier, religion in general, and Islam in particular, is an important and serious matter in UAE society, and tension may surround the discussion of culturally sensitive topics including prostitution, alcohol consumption (e.g., pubs, bistros, wine), eating pork and the symbolism of the pig (e.g. 'piggy-banks'); sex(uality) and relationships (gender issues, de facto relationships, polygamy, homosexuality and transgender), evolution theories, and Shari'a law versus secular law (e.g., Islamic banking: finance and insurance, divorce and repudiation). In dealing with such topics, teachers may well face resistance and rejection if students feel that their values are being criticized or judged by the Other. To illustrate this point, I can mention a tension that took place in a school where I worked in Dubai. A Western colleague, who witnessed a group of Emirati students racing in and out the classroom, muttered: "you're like a bunch of pigs!". The students were offended by the teacher's remark, which was rapidly relayed throughout the school, first among students in this class, then in other classes and to the teaching faculty. Some of the students reacted by refusing to fully cooperate with this teacher in the classroom (not paying attention, refusing to answer his questions or follow his instructions). The incident was soon reported to the school authorities, who summoned the teacher for explanation and counselling.

Gender segregation is another sensitive issue, both from social and religious perspectives. It is accepted and practised in most cases throughout the government education system in the UAE, and when it was suggested as a topic of discussion, students resisted because it fell within the area of religious and cultural practices: engaging in a debate for or against segregation may be perceived as a challenge to students' religious beliefs. In a debate on gender segregation in a language course at a male-only institution in the UAE, one student refused to participate or allow the class debate to continue: for this 
student and some others, gender was a part of their religious identity and traditions, and therefore it was not up for debate.

In relation to gender issues, a Western male teacher faced resistance and rejection when teaching Metamorphosis to a female-only class. Students resisted primarily because a (Western) male was discussing sensitive topics (e.g., sexuality) with them, topics which are generally only talked about between members of the same gender (Blaik-Hourani et al., 2011). On the other hand, a female Western-trained teacher taught Chekhov's The Lady with the Dog with the same class without evident tension or resistance, because it was discussed between members of the same gender and, as mentioned before, the topic was not presented in opposition or in contrast to their values and beliefs, but was associated with the values of the 'alien' Other (Blaik-Hourani et al., 2011). For Western-trained teachers, these topics have to be dealt with carefully, in order to engage students without inciting resistance or creating tension.

Engaging Emirati students in discussing politics can be a significant (and counter-productive) challenge as discussing politics, like some aspects of gender and culture, can be sensitive even when it has little or no apparent religious connotation. Topics such as sex education or terrorism, or expressing one's political opinion in contradiction of established political (and spiritual) views and authorities, may be viewed as covert ways of pushing cultural and socio-political values (e.g. democracy, human rights) which are seen as 'Western' rather than universal.

A very telling incident that occurred in a military institution in the UAE where I worked serves to illustrate this area of tension. A Western teacher copied a text (taken from a newspaper - see student copied version in Figure 1) on the classroom whiteboard and then discussed it with students. The teacher used the text as an opportunity to criticise Arab leaders (as being authoritarian like Muammar Qaddafi) and to present Arab-Islamic cultures and values as backward (compared with Western societies). After having discussed the newspaper article, students were asked to copy it in their notebooks to read it at home for further discussion. The underlined phrases in the copied article below are from the teacher, who used them as key words to focus his discussion and comparison between Western and Arab-Muslim countries.

Oil-rich Libya slowly emerges from behind the face and rhetoric of Muammar Qaddafi

For years terrorist actions made it an outlaw nations [sic], but the UN liteed [sic] sanctions in 1999. In this land of contrasts, modern values clash with traditional Islam, more women graduate from college than men, and the Great Man-Made River carries water from the desert to the coast. Journey through Libya as author Andrew Cockburn narrates to a slideshow of photographer Reza's images.

Figure 1: Student text copied from the classroom whiteboard (reproduced verbatim).

The students, shocked by the views expressed in class by their teacher, passed on the copied article to their parents. The latter, some of whom were influential in the military and police hierarchy in the different emirates, found the article inappropriate in this academic context and the views expressed by the teacher objectionable. The following day, some parents contacted the military school authorities to voice their disapprobation and concerns over the article and the views expressed. The parents' reaction created shock waves in the school as the military and the civilian school authorities were summoned for an urgent meeting to discuss the matter. Unfortunately for this colleague, this critical incident marked the beginning of the end of his employment - he lost his job before the end of the academic year. 


\section{Conclusion}

This article has discussed a range of strategies used by Emirati students' to (re)construct identities for themselves and others in their encounters with Western-trained teachers. These included, for example, annotating, questioning and even deriding some contents of the textbooks and teaching materials. Faced with teacher who they feel transgress their religious values and beliefs, I have found that students sometimes refuse to cooperate with their teachers (e.g. disobeying or refusing some topics) and/or complain about them to their parents or school authorities. These students possess their own identities constructed on their cultural values and religious beliefs, which are grounded on Islamic educational principles. In addition, they are socialized in a conservative Muslim culture that has inherited its pedagogies and education traditions from the Islamic education model. They encounter teachers who not only are shaped by liberal and secular views and trained according to Western epistemologies, but have also inherited Judeo-Christian educational philosophies. This encounter has resulted in tensions and resistance on the part of the students which have been discussed in relation to a range of critical incidents in the classroom setting. These critical incidents in cross-cultural educational encounters indicate that the Emirati students use the symbolic and cultural representations of their Westerntrained teachers not only to contest and reject the Other, whom they see as the covert agent of the target culture, but to construct and validate their own identities.

Based on the critical incidents involving Emirati students and Western-trained teachers discussed in this article, it could be argued that effective and successful cross-cultural teaching in this educational setting requires Western-trained teachers to adapt their positionality, choice of teaching material, textbooks, epistemologies, and, above all their cultural symbolism to the cultural space (epistemologies, cultural and religion values) of their Emirati students. This article suggests that for Emirati students, their values not only impact considerably on the ways they construct their own identities, but they also shape their attitudes towards learning from their imported Western-trained teachers.

Western-trained teachers who embark on a professional journey in the UAE in particular, or the Gulf region more generally, need to be explicitly prepared for a successful encounter with their Emirati students. For example, in this particular teaching context, they need to select appropriate materials, be aware of what is NOT appropriate and take a specific approach to certain topics. Most importantly, given that both Emirati students and Western-trained teachers operate sometimes within different social, cultural and religious paradigms, it is also essential to find a 'third place' to allow both Emirati students and their Western trained teachers to substantially reconcile cultural "unity and diversity" (Lo Bianco et al., 1999, p. 5) in their classrooms. The third place would serve as a bridge between these two, since culture

is difference, variability, and always a potential source of conflict when one culture enters into contact with another. (Kramsch, 1993, p. 1)

A 'meeting place' free from identity and cultural threats is always needed in this cross-cultural educational encounter in order to freely explore cultural differences while helping students to feel safe and comfortable (Kramsch, 1993).

\section{References}

Ahmed, S. (2011) Casting Arab culture. In Christina Gitsaki (Ed.), Teaching and Learning in the Arab World, (119-137). Peter Lang.

Barazangi, N. H. (1995) Religious Education. In John L. Esposito, (Ed.), Oxford Encyclopedia of the Modern Islamic World. http://ecommons.cornell.edu/bitstream/1813/7769/1/NHB ReligiousEd 1995.pdf 
Barnard, A., McCosker, H. \& Gerber, R. (1999). Phenomenography: a qualitative approach for exploring understanding in health care. Qualitative Health Research, 9(2): 212-226.

Blaik-Hourani, R., Diallo, I. \& Said, A. (2011) Teaching in the Arabian Gulf: arguments for the deconstruction of the current educational model. In Christina Gitsaki (Ed.), Teaching and Learning in the Arab World. (335-355). Peter Lang.

Boyle, R. (2012). Language contact in the United Arab Emirate. World Englishes 31(3): 312-330.

Brookfield, S. D. (1990). The skilful teachers. San Francisco: Jossey Bass.

Canagarajah, S . A. (1999). Resisting linguistic imperialism in English teaching. Oxford University Press: Oxford.

Clarke, M. (2007). Language policy and language teacher education in the United Arab Emirates. TESOL Quarterly 41(3): 583-591.

Findlow, S. (2006). Higher education and linguistic dualism in the Arab Gulf. British Journal of Sociology of Education. 27(1): 19-36.

Findlow, S. (2008). Islam, modernity and education in the Arab States. Intercultural Education 19(4): 337352.

Grossberg, L. (1996). Identity and cultural studies - Is that all there is? In S. Hall \& P. Du Gay (Eds.), Questions of cultural identity, (87-107). London: Sage Publications.

Hall, S. (1996). Introduction: Who needs 'identity'? In S Hall and P. Du Gay (Eds.), Questions of cultural identity, (1-17). London: Sage Publications.

Hall, S. (1997). Cultural identity and diaspora. In K. Woodward (ed.) Identity and difference, (51-59). London: Sage publications.

Hall, S. \& Du Gay, P. (Eds.), (1996). Questions of cultural identity. London: Sage publications.

Halstead, J.M. (2004). An Islamic concept of education. Comparative Education 40(4): 517-529.

Holland, W. (1996) Mis/taken identity. In E. Vesta \& S. Castles (Eds.), The teeth are smiling: The persistence of racism in multicultural Australia, (97-111). St Leonards, NSW: Allen \& Unwin.

Ibrahim, A., Al Kaabi, A., \& El Zaatari, W. (2013). Teacher resistance to educational change in the United Arab Emirates. International Journal of Research Studies in Education, 2(2):1-11

Karmani, S. (2005). Petro-linguistics: the emerging nexus between oil, English, and Islam. Journal of Languages, Identity, and Education 4: 87-102.

Kazmi, Y. (2003). Islamic education: Traditional education or education of tradition? Islamic Studies 42(2): 259-288.

Kramsch, C. (1993). Context and culture in language teaching. Oxford: Oxford University Press.

Lo Bianco, J., Liddicoat, A. T. \& Crozet, C. (1999). Striving for the third place: Intercultural competence through language education. Melbourne, VIC: The National Languages and Literacy Institute of Australia. Marton, F. (1981). Phenomenography: describing the world around us. Instructional Science 10: 177200.

Marton, F. (1986). Phenomenography: A research approach to investigating different understanding of reality. Journal of Thoughts 21(3):28-49. 
Ministry of Education. (2008). The Ministry of Education strategy 2010-2020: aiming at accomplishing a score of 10/10 in all of its initiatives. Abu Dhabi: Ministry of Education.

Nasr, S. H. (2012). Islamic pedagogy: An interview. Islam and Science 10: 7-24. Interviewed by Memon Nadeem.

Phan, Le Ha (2007). Australian-trained Vietnamese teachers of English: culture and identity formation. Language, culture and curriculum 20(1): 20-35.

Phillipson, R. (1992). Linguistic Imperialism. Oxford: Oxford University Press.

Phillipson, R. (2009). Linguistic Imperialism Continued. Hyderabad: Orient Black Swan.

Piaget, J. (1937). La Construction du Réel chez l’Enfant. New York: Basic Books.

Piaget, J. (1967). Biology and Knowledge. U.S.A.: Chicago University Press.

Reed, G. G. (2001). Fastening and unfastening identities: negotiating identity in Hawai'i. Discourse: Studies in the cultural politics of education 22(3): 327-339.

Reinert, K. \& Rajan, R. (2009). The Princeton encyclopedia of the world economies. Princeton University Press.

Syed, Z. (2003). The sociocultural context of English language teaching in the Gulf. TESOL Quarterly 37(2): 337-341.

Vygotsky, L. (1978). Interaction between learning and development. In M. Gauvain and M. Cole (Eds.), Mind and Society,(79-91). Cambridge: Harvard University Press.

Wilkins, S. (2001). International briefing 9. Training and development in the United Arab Emirates. International Journal of Training and Development, 5 (2): 153-165.

Woodward, K. (Ed.), (1997). Identity and difference. London: Sage Publications.

Yuen, K.-M.. (2001). The representation of foreign cultures in English textbooks. ELT Journal 65(4): 458466.

Zevin, J. (2000). Social studies for the twentieth century: methods and materials for teaching in the middle and secondary schools. London: Longman.

${ }^{1}$ This paper was first presented at the conference Cross-cultural Pragmatics at a Crossroads II: Linguistic and Cultural Representations across Media (University of East Anglia, UK, 29 June - 1 July 2011). I would like to acknowledge Phiona Stanley's contribution to the ideas and discussions that shaped the original version of this paper.

2 Even though some of the critical incidents discussed here took place in secondary school contexts, they are relevant to university and college levels in the UAE, given that textbooks and teaching materials used in teaching at these levels (especially of languages such as English) tend to be from the same Western publishers and constructed from the same perspectives. In addition, Emirati students, whether they are in secondary or university/college levels, share the same religious and cultural values. 